\title{
The Russian System of Financial Law
}

\section{Tsindeliani Imeda Anatolevich}

The Head of Financial Law Department of the Russian State University Justice, the Professor of Financial Law Department, The Candidate of Legal Science, the Associate Professor Email: imeda_pravo@mail.ru

\section{Doi:10.5901/mjss.2015.v6n2s4p47}

\begin{abstract}
The financial law in prerevolutionary Russia (up to 1917) are examined, during the Soviet period and in the modern period of the development of the Russian Federation. The social relationships in the sphere of public and private finances are the subject of coordinating regulation by both public and civil branches of law. It entails the necessity of formation of inter-branch units particularly in the sphere of finance legal regulation. The modern system of financial law is presented by the following some sub-branches: tax law, emission law, finance and control law containing a big number of financial law institutions.
\end{abstract}

Keywords: financial law institutions; banking law; tax law; budgetary law; emission law; finance-control law.

\section{Introduction}

The evolution of such categories of financial law as its subject and system is a very important problem. The definition of the main evolution stages of these categories allows to define propositions which has left in modern content and will reflect the points which will help to realize these categories from the very beginning.

\subsection{Different approaches to the determination of the subject of financial law and its system have touched prerevolutionary stage of the development financial.}

V. A. Lebedev identified the borders of financial law as a law one and the theory. He defined them in the following way: «the rules of financial economy shaped in well-known legislative regulations will be financial regulation or financial law. The theoretical research of all these general definitions are finance, financial economy, financial law composes financial theory» (Lebedev, 2000: 36). He recognized that the subject of financial law and subject of financial theory were identical but they differed through a way of research. He related law-dogmatical research of financial regulation to the subject of financial law and political research of financial regulation to the subject of financial theory. It's very important to stress that while V. A. Lebedev defining the role of financial theory, he said that it « outlines borders where in which the financial activity of the State should operate»(Lebedev, 2000: 41). The author didn't make a deep difference between financial law and financial theory. As follows the determination of structural elements of the financial law and financial theory were considered as identical. The author particularly recognized the following component parts of financial law and financial theory:

- the review of state needs, the definition of financial economy and financial institutions;

- the review of state revenue (income) and duties;

- the description of the structure of local (zemstvo) and communal financial economy;

- the examination of ways of covering of extraordinary needs i. e. the theory of state credit (Lebedev, 2000: 144).

We can see that the author considered that financial law and financial theory were interrelated phenomena with common characteristics. In fact, these categories were considered by him as complex phenomenas which were the result of interaction of economy, politics and law.

Another author I. I. Yanzhul examined the correlation of financial law and financial theory and considered that "financial law researches on the base of the experience how the State really gets its material resources and financial theory on the base of financial law and laws of national economy draws up common rules how the State should get them" (Janzhul, 2002: 47). As follows he didn't delimit the subject of financial law and financial theory, but he pointed that the ways of examination were different. I. I. Yanzhul didn`t draw distinguishes between that categories directly. Sometimes 
he used the term "financial theory" and sometimes "financial positive law".

It was caused by the fact that financial law and financial theory were considered not only as a generation of political economy and the state law but there were no problems of branch identification in prerevolutionary Russia. The author's approach to defining of elements of financial theory and the effect of financial law is interesting. I. I. Yanzhul supposed that the financial theory should be included only in theories about public income excepting theories of public expenses (Janzhul, 2002: 53). According to his opinion the system of public income consisted of ordinary and extraordinary public income, but the system of ordinary public income consisted of private-law sources; regalia, taxes and duties.

We should recognize that the researches by I. T. Tarasov are more complicated because he delimited financial theory and positive financial law (Tarasov, Isaev, 2004). In his opinion public income and expenses and their administration were the subject of financial theory, and the main purpose of the theory was a disclosure of phenomena's rules in the sphere of state economy in connection with the analyze of legal rules which regulated that economy (Tarasov, Isaev, 2004: 51). As follows, the author expanded borders of financial theory having included public expenses. Instead of previous authors who concentrated on only public income in the sphere of financial law, I.T. Tarasov included a systematic description of all rules and norms which dealt with public income and expenses and also their administration in compliance with the views of the State about political and civil freedom and the root conditions of the people (Tarasov, Isaev, 2004: 52-53). It is obvious that the theory of financial law in pre-revolutionary Russia covered wider scope than the modern imagination about financial theory. I. T. Tarasov especially emphasized "This theory teaches not only what it is and why it occurs but also what it is in this range according to economic laws, meaning and purpose of the State and concepts of good and justice" (Tarasov, Isaev, 2004: 53). Defining the financial law the author didn't depart from propositions about it was the complex of provisions specified state-economy range of certain people in a certain age.It is rather interesting that the author considers the codification extremely difficult. I. T. Tarasov outlined that the systematization was preceded by the proper classification which was fixed by the complex of meanings obtained in a certain subject and was distributed for comparison according to a number of rows, groups etc. (Tarasov, Isaev, 2004: 59).

As I.T. Tarasov considered that the system of financial law consisted of three parts: introduction, general and special parts. He divided the introduction of financial law into the subject of financial law and its definition, connections of financial law with other sciences, with other state bodies, method and system, history of financial institutions. He attracted organization of financial administration; power of financial bodies; measures providing order, correctness and regularity in the sphere of financial administration; cashkeeping, accounting, financial statement; control and revision institutions; responsibility (liability) to the general part of financial law. In the special part the author regarded three big sections which had a detailing subdivision namely natural economy, money economy and credit economy (Tarasov, Isaev, 2004: 60). It should be notice that I.T. Tarasov characterized money economy of State exclusively with the help of the category of duties (podati) by reason of predominance under the other of public income sources. Tarasov's idea about the subject of regulation of financial law is the magnificent contribution to the development of the theory of financial laws and responsibility in the sphere of finances and is actual and important nowadays. First of all he considered financial laws as a way of restriction of the State treasury and taxpayers rights.

A. A. Nikitsky explained the definition of financial law in subjective and objective senses. He defines it in objective sense as the whole complex of rules regulating financial economy of State and local authorities. And in subjective sense it was authority under a law to person or public union on decision-making in the financial state economy (Nikitinskij, m1910: 11). There were such elements of financial state economy and structural elements of financial law respectively as budgetary law and state control.

The work by E. N. Berendts (Berendts, 1914) became a very important stage in the development of financial law theory. First of all he described the component of that theory in a systematic manner. The author strictly differentiated such categories as "theory about finance", "theory about state economy", and "theory about financial law" (or financial law). He stated that the subject of financial law was legal rules which were laid down in the basis of economic activity of State power and its bodies (Berendts, 1914: 10). It is characteristically that in the work mentioned above public powers in state economy and status of nationals in that sphere was described with a view to legal regularities and analyzed budgetary law and tax law and such institutions as the state control and financial government.

According to a lecture course of V.G. Jarockij financial law was a complex of legal rules regulating state financial activity (Jarockij,1898: 4). He decided that state financial activity was identical to state financial economy. According to Jarockij it was necessary to delimit theory of financial law and financial law itself which was a complex of legal rules. He divided the course of financial law into the following parts:

- a financial economy order and its bodies

- $\quad$ state needs or purposes of public income 
- ordinary public income

- financial economy of local authorities

- extraordinary state income (state credit) (Jarockij,1898: 59).

According to the analyzes of the works by such classic authors as S.I. Ilovajskij, I. H. Ozerov, I. Patlaevskij, D. Lvov, the problems of financial law subject and its system were not the object of substantial attention. Recognizing a young age of not only theory of financial law but also financial law these scientists made ambiguity of these categories. 1904).

S.I. Ilovajskij considered that financial law was a state science and related it to financial state legislation (Ilovajskij,

I. Patlaevskij related financial law to financial state legislation and defined it as "more or less successful theory of finance supplement to conditions of a certain State in the form of a law" (Patlaevskij,1885: 19). And the content was determined with three parts: theory about public income; theory about public expenses; theory about a balance between of receipts and expenditure and state credit (Patlaevskij,1885: 23). D. Lvov had the same position and determined the subject of financial law as a supplement of common principles of financial science to positive legislative (Lvov, 1887: 6). He wrote that its content consisted of three parts: public expenses, public income, and public accountability. Local and imperial finances were considered as applied part. But I. H. Ozerov made a general accent on studying of financial law institutions and stated that the finance theory belonged to both economic and legal sciences. He stated that "financial law is a result of struggle and it cannot strongly systematized" (Ozerov, 1911: 24, 40).

In prerevolutionary Russia theoretical backgrounds of financial law based on cameralistics, political economy, theory about state economy. As a result theory of finance and financial law were thickly filled with theoretical categories related neither to finance nor financial law. Cameralistic sciences influenced seriously the prerevolutionary finance law, another words, sciences about the best administration of state assets and public fields or a treasury in general. A major goal of cameralistic sciences was a build-up of financial state base in prerevolutionary Russia.

As a result prerevolutionary legal-financial literature didn`t represent strict definitions of matter and system of financial law. Ambiguity of the marked categories shows a weak legal readiness of theoretical propositions of financial law in prerevolutionary Russia. But it should be recognized that some institutions of financial law were deeply developed theoretically (institutions of public income, taxes and duties and public expenses). The intensity of their development was very deep and they have been actual till our days.

Nevertheless in prerevolutionary Russia there were no special legal designations of financial law parts in the works of many scientists.

But the finances of community of commons (zemstva and another forms of communal self-government existed in prerevolutionary Russia) were a component of theory about finance and financial law. Nowadays they are called municipal finances. And this fact emphasizes a right tendency according to institutions of local finance which are components of modern financial law.

In conclusion it should be noticed that the definition of the subject of financial law in prerevolutionary Russia had a complex character. It was defined as a symbiosis of economic and legal basis of state economy administration. It affected a determination of intensional structure of financial law. The structure of prerevolutionary financial law in Russia was represented by the following big divisions which were divided into sections and parts: state income; state expenses; financial administration backgrounds and financial bodies; sources of covering of extraordinary expenses; financial sources of commons (zemstva).

\subsection{The formation of complex units (complex of institutions) in the structure of financial law}

The first textbook devoted to finance law (Gurvich, 1940) was published in 1940. In this textbook the subject was defined as legal relationships between the USSR higher state bodies and union republics in the sphere of draft, adoption and fulfillment of budget, legal relationship between different parts of financial system and between financial bodies and socialist factories and population.

In essence the characteristic of relationships related to the subject of financial law was considered in the light of class character and strong centralization of the whole process of financial system administration.

Financial law as a branch of law was regarded as a complex of rules which regulating:

- a drafting, adoption and fulfillment of budget process;

- factories' compulsory payments to budget;

- taxes and duties;

- state insurance;

- financing of national economy, social and cultural activity, the administration and the defense; 
- $\quad$ short-term crediting and amounts;

- monetary circulation;

- financial control.

The structural elements the of branch were the following:

- budgetary law. It included rules concerned to the USSR rights and its bodies from the sphere of drafting, adoption and fulfillment of budget, budgetary structure, and distribution of income and expenses between parts of the budget system. There were a few groups of legal rules in budgetary law such as rules related to fulfillment of the budget; rules related to income part of the budget; rules regulating the direction and use of budget funds;

- state credit. It included rules related with state loans, rights and obligations of both the State and loan recipients;

- monetary circulation. This section consolidated rules related to emission rights of the State Bank, the emission of bank and treasury notes and small coins, a control of cash assets, cash and credit planning and rules related with the currency regulation of both foreign currency and precious metals.

Despite of some archaism of this textbook, the latter fixed the idea about separability of financial law. Neither this textbook nor textbook published in 1946 (Rovinskij,1946) contained a detailed analyze of the subject and system of financial law. In the mentioned work the subject of financial law regulation was defined as social relations arising from accumulation and distribution of money assets by the State through financial system. Financial law was defined as a complex of legal rules regulating relations in the sphere of budget, taxes, state credit and savings business (sberegatelnoe delo), state insurance, state social insurance, short-term credit and amounts, monetary circulation organization and a financial control. But the definition of financial law was not given through generic features but by enumeration of types of relationships related to the financial system of that period.

There were no criterions of forming financial law as a branch of law in the textbook. But this textbook contains rules included in a system of financial law:

- $\quad$ the organization of financial state system;

- $\quad$ the composition, direction and sources of public expenses financing;

- $\quad$ the system of public income (tax and non-tax payments in the budget);

- $\quad$ the competence of bodies of state power and administration and its budget rights; distribution of the income and expenses between separate types of budgets; and fulfillment of budget order; budgetary financing of national economy order, administration and defense; cash fulfillment of budgets order; draft and adoption of financial statement about budget fulfillment order; control order of budget fulfillment;

- the organization of public credit and savings business; the issue and discharge of state loans order; interrelationships between state savings banks and budget and credit systems;

- the organization of public property and personal insurance and its relationships with budget and credit systems;

- the organization of state monetary system, an order of planning and regulation of monetary circulation and foreign currency circulation;

- the organization of short-term and long-term crediting and accounts in national economy; interrelationships between budget and credit systems in the process of budget fulfillment;

- the organization of public financial control and order of its execution.

The general criterion for the inclusion of legal rules to financial law was designated as a direct link with relations regulation arising from the process of money funds accumulation and its planning distribution and using (Rovinskij, 1946: 15). It was recognized that there were relations in the process of financial state activity regulating not only rules of financial law but also of other branches of law.

In his tutorial E. Rovinskij determined the subject of financial law as financial relations arising in the process of financial state activity. He determined the branch of law as a complex of rules regulating financial relationships in a financial state activity in the view of provision of the fulfillment of state tasks and functions (Rovinskij, 1957). He considered the system of financial law was based on taking into account of relations specifics regulated by legal rules. The systematization of financial legal rules was made with highlighting of general and special parts. The general part included rules fixing the principles and legal forms of financial state activity, a competence of state bodies which carried out that activity constituting a single financial system, forms and methods of financial control. The legal financial institutions regulating certain homogeneous group of financial relation formed the special part. They were budgetary law, tax law, public loans and savings business, public insurance, rules relates to public expenses and budget financing and stated crediting and accounts basics, monetary system and currency planning (Rovinskij, 1957: 17-18). 
The tutorial determined financial law strictly as a branch of law carrying out the form of financial state activity regulation by means of financial relations.

Significant influence on the development of financial law theory in relation to its subject and system had the article written by R. O. Halfina (Halfina, 1952: 182-213). Criticizing the definitions in the textbook published in 1946, R. O. Halfina stated out that a determination of the subject should point on substantial features distinguishing it from analogous phenomena but not homogeneous. But it had to reveal the common characteristics which united all kinds of that phenomenon. She also criticized a reckoning of relations occurring in the sphere of savings business, state insurance, state social insurance, short-term credit and accounts in financial law (Halfina, 1952: 190). She considered the subject of financial law included relations arising in the process of planned accumulation and distribution of money state assets. As a matter of fact R. O. Halfina suggested principles of the formation of financial system law. She outlined general and special parts but criterions for its difference were specific. Since the general part had to characterized all legal specifics of financial law as an area of law and that's why a general criterion was presented as legal specifics and legal principles of law area and only after economic content of rules and relations. Therefore the general part consisted of the following sections: sources of financial law; general principles of financial law; bodies exercised financial activity; financial acts; financial relations; financial control; provision of due course of financial law. She suggested to take the economic content of institutions determined the legal characteristics for forming of the special part. According to the composition of the special part she suggested to include budgetary law; tax and dues; duties; income from state assets; organization of credit; monetary system; financing of national economy, culture, administration and defense (Halfina, 1952: 210).

B. N. Ivanov (Ivanov, 1967: 34-67) differentiated the following main sections of the general part: legal basis of financial state activity; bodies running financial activity and financial control. The author suggested to put the rules stating the basics of finance and credit system and monetary system, rules delimiting rights of public authorities in financial sphere, rules defining the organization of financial activity public factories and state institutions and the basics of legal status of citizens in financial sphere to the general part. He considered that the special part of financial law should include the following institutions: budgetary law; compulsory payments of public factories and organizations in the budget and tax law; non-tax income; public credit; public property and personal insurance; public expenses; an organization of bank credit and non-cash payment an organization of currency and exchange operations (Ivanov, 1967: 66). Credit and amounts relations had to be considered as complex legal institutions because they were in the sphere of regulating both financial and civil law. The author paid a special attention to such the exclusive finance-law nature of those institutions as bank crediting, public credit and public property and personal insurance.

T. S. Ermakova gave a very interesting decision of determination of financial law system in her article (Ermakova, 1975: 72-80). She considers the base of the formation of the system is in the essence of financial relations themselves and accordingly chains of the financial system and she besides does not take into consideration the legal criterion. She presented the system of financial law as a complex of the following stages: sub-branch of law - institute - sub-institute. The author defines the system of financial law through three sub-areas of law. Namely, rules system regulating finance relations of factories and sectors of economy; rules system regulating nationwide finance; rules system regulating credit relations.

She points out those two institutes in the first sub-branch of law. They are the following:

- institute regulating financial relations of industrial and economic organizations and its higher administrative and economic bodies (ministries);

- institute regulating financial relations of cooperative and public organizations in the economy.

- The second sub-area of law consists of the following institutes:

- budgetary law including rules devoted to regulation of tax and dues collection and rules regulating the order of the national economy financing;

- public and personal insurance.

At last the third sub-area of law consists of the two following institutes: public credit and bank credit (Ermakova, 1975: 79-80).

Cypkin's approach to problems of forming of especial part financial law of system is rather interesting. First of all the author was the opponent to the division of sub-branch of law in law system. He also denied the use of such definitions like "super-institute", "large institute" and "large section". He structured a special part into three sections "rule - institute -branch of law". He said that "section of branch of law" had wider content and admitted less degree of homogeneity, typicalness of regulated relations than legal institute (Cypkin, 1983: 24). According to his position general sections, institutes of the special part were identified with general sections of financial system and a basis for a separation had specifics of finance and economic groups which defined specifics of certain methods and forms of both money assets accumulation and distribution (Cypkin, 1983: 25). That's why he considered that the special part of financial law consisted 
of the following sections:

- budgetary law;

- legal regulation (or law regime) of factories, organizations and national economy sectors finance;

- public property and personal insurance (Cypkin, 1983: 30);

- $\quad$ rules regulating credit relations (Cypkin, 1983: 35).

Examine the problem of financial law construction, E. A. Rovinskij pointed out such feature of financial law as a presence of two legal institutions, regulating the whole complex of relations which were the object of finance legal influence and mixed (complex) institutions. In the sphere of those institutions the complex of financial relations was regulated by both financial law and other branches. Common function of money assets mobilization and expenditure by State and common source of law for branch of law were the criterion for the inclusion into the system of financial law of the mixed institutions. (Rovinskij, 1960: 93). Being agreed with a classification of rules of general and special parts he suggested to include the general part rules stating main principles and legal forms of financial state activity, competence of its bodies forming united financial system, forms and methods of financial control.

The special part of financial law was presented by a complex of the single institutions:

budgetary law, compulsory payments of state factories and organizations, tax law, state loans and savings business, state insurance, state expenses, monetary and credit system (Rovinskij, 1960: 94). E. A. Rovinskij raised a question about creation of financial code containing legal rules which should regulate financial relations in succession (Rovinskij, 1960: 95).

Examine the system of financial law A. I. Hudjakov admitted reasonable the separation of general and special parts. He formed the general part of financial law consisting of the following institutions: law basics of financial state activity; law basics of monetary system; finance administration; law regulation of finance planning; financial control. The forming of the special part was referred to financial state structure, i.e. the special part of branch of law was formed of presence or absence of according finance legal institution in state structure. After that that's why the author represented the special part consisting of the following sections: budgetary law, banking law, finance and insurance law, finance and economy law.

The further structurization of the special part supposed the separation of certain institutions (Hudjakov, 1988: 7582). A. I. Hudjakov denied the possibility of existing of such institutions as legal regulation of state credit and legal regulation of state social insurance as such institutions were absent in financial state system. He also denied such institutions as public income and public expenses, because any revenue and expenses were integral part of certain money fund (Hudjakov, 1988: 75-80).

Examine that scientific positions concerning the subject and system of financial law in the Soviet period of it development it is necessary to take into consideration that in was a historical stage of the state development which characterized the absolute priority of state interests over the interests of person and even society in the whole. The diversity of approaches to the structural elements of the branch of law helps to conclude the following:

- the absence of unified criterions of a separation of institutions and sub-institutions;

- some authors denied sub-branches of law in the structure and proposed the existence of sections and didn 't separated them from financial law branch;

- there were mutually exclusive conclusions about inclusion and non-inclusion of different institutions into financial law system;

- the most part of scientists denied possibility of existence of finance-and-legal institutions without existence analogous finance and economic ones.

We should admit the importance of the scientific discuss about subject and system of financial law. Practically during the Soviet period it was scientifically based and argued the existence of the separate branch of law in state law system (Pavljuchenko, 2008). This branch of law has its own subject and the method of regulation. The formulated basic financial categories have magnificent influence on the development of financial law theory and formulated the imagination about structural elements of financial law system. It has been adopted in the modern financial law literature. The existence of two big structural elements of the financial law system have been reasonably argued: the general and special parts consisted of sections or sub-area of law and they consist of finance and law institutions which unified the relevant financial legal rules. But there was a debatable question - what structural elements were forming general and special parts of financial law and what sub-area of law and institutions should be excluded or included into the system of financial law. Taking into account that principles of the Soviet economy and total State participation in all parts of existing Soviet financial state system, the system of financial law and especially its special part had a scaled character. In fact all elements of financial state system were provided by the relevant finance and law institutions despite of some of them had the relevant institutions in other areas of law. Structural elements of financial law were sub-institutions - institutions - 
sections (sub-branches of law), but unified criterions of alignment and forming structural elements were absent. No doubt that there were vertical and horizontal links between financial legal rules which provided a forming of structural elements of financial law system. Those links helped to form not only relevant structural elements but ensured a close connection between structural elements guarantying direct and reverse links between them and successful functioning. And it was the reason of the formation of complex units (complex of institutions) in the structure of financial law ensuring the regulation of the relevant public relations. Simultaneously the of creation of internal complex units facilitated to a construct of intersectoral units with administrative law, civil law, labor law and law of social maintenance and etc. But that there was no enough attention to the problems of financial during the Soviet period.

\subsection{Changes in political and economical state system have touched basics categories of financial law, particularly subject and system of financial law.}

A transformation of the previously existing elements of financial system, the appearance of new elements significantly influenced on the modern stage of financial law development. It is possible to point out two directions in the modern financial law literature dealing with the development of financial law and determination of subject regulation and institualization of branch of law. The first direction can be marked as traditional. It tends a modernization of wide theoretical heritage of the soviet finance-and-legal theory. The second one can be designated as revolutionary as it tends to full revision of the traditional approaches of examination of the fundamental categories of financial law. The attempt to review financial law in new politics and economic conditions has lead to the appearance of rather original directions of the financial law theory.

G. A. Tosunjan and A. Ju. Vikulin advanced a hypothesis about forming of new branch of law. Its subject is public and private (corporate) finances. They consider that the relations arising from finances always have suggested strict public character. According to these authors a new financial law has a specific system. It is characterized by internal multipartiteness, differentiation on relative, independent (autonomous), but interrelated parts between them and links between structural elements have a stable character and provide integrity of branch of law (Tosunjan, Vikulin, 2003: 711). The system of new financial law has the following structural elements: budgetary law, tax law, banking law, insurance law, currency law, investment law, securities law, legislation of protection of competition on securities market, securities market legislation, legislation of financial control and auditing activities, legislation about counteraction on money laundering of the proceed from crime (Tosunjan, Vikulin, 2003: 11). But these authors consider that the system of new financial law supposes dividing into a special branch including two sub-branches - budgetary and tax law as, and complex branches of law - banking law, insurance law, legislation of protection of competition on securities market, securities market legislation, legislation of financial control and auditing activities, legislation about counteraction on money laundering of the proceed from crime (Tosunjan, Vikulin, 2003: 11).

A new concept of financial law was supposed by N. M. Kazancev. It is supposed to interpret financial law as law i.e. to do relevant in law actions with help finance and financial estimates being under a certain jurisdiction of a State or another subject with financial jurisdiction (Kazancev, 2009: 29). The author considers financial law both public and private law (Kazancev, 2009: 29). He determines the composition of financial law as a authority to acquisition real national assets at a certain size according to their value. The author's idea about financial law system is very interesting. He considers that financial law structure cannot be structure in the form of a tree. Financial law system is a networking structure where number of various hierarchical subsystems can be outlined (Kazancev, 2009: 31). Another author A. N. Kostjukov states that financial law system is a complex of parts and elements of financial law characterizing its internal construction and isolating it from other branches of law. Financial law system itself represents a pool of unified by legal nature elements in structural and integral unity which has relative stability, autonomous functioning and interrelation with environment (Kostjukov, 2002: 27-28). The author gives a classification of financial law system elements according to various basics. He characterized the horizontal structure of financial law branch by the following elements: financial law rules, financial law institutions forming sections and sub-branches united in the parts of financial law. The author outlines a horizontal division of the branch and a vertical construction based on the legal effect of financial law normative materials (Kostjukov, 2002: 30). On the basis of the analyze A. N. Kostjukov shows system of financial law consisting of general and special parts. The general part includes such institutions as financial law rules, finance and legal status of party to financial law, financial law relations, legal facts in financial law, financial control. The special one is represented by budgetary and tax sub-branches and the following sections:

- public (local) income;

- public (local) expenses;

- banking law; 
- insurance activity;

- currency regulation;

- monetary circulation and amounts;

- auditing activities;

- public credit;

- legal regulation of factories finance(Kostjukov, 2002: 33-34).

N. M. Kazancev determines system of financial law as consisted one of the following sub-branches:

- extraction, production and rotation of precious metals and stones;

- emission (banknotes, securities, financial derivatives) activity;

- credit and bank regulation;

- currency regulation;

- accounting;

- insurance;

- finance and estimation;

- regulation of securities markets;

- collecting;

- supervisory and control(Kazancev, 2009: 33-34).

He states that institutional elements of financial law can be grouped with functions of finance and law administration. Each function is the secondary from relevant rights of finance and law administration. The meaning of division of the sub-branch of law consists of provision of autonomous regulation of each law branches and its subbranches between each other (Kazancev, 2009: 36-37).

Dealing with modern problems of construction of financial law system M. V. Karaseva (Karaseva, 2006: 94-99) and makes a conclusion that finance law regulation has turned into property and law regulation. She considers that the system of financial law should be constructed with a base of two criterions, economic and legal. The financial system and cash flows serving is the economic criterion of the formation of the financial law system. And the legal criterion is the classification of property relations (Karaseva, 2006: 97).

O. N. Gorbunova defines the subject of financial law (as a branch of law) as social relations forming in the process of financial state activity. And the system of financial law consists of finance law institutions and sub-branches (Gorbunova, 1998: 22-23).

Professor E. M. Ashmarina made a certain contribution into the expansion of the subject and its emergence into the system of new sub-branch (Ashmarina, 2009: 4-12; Ashmarina, 2004). She relates the following of social and financial relations:

- relations concerning formation, allocation and use of centralized state and municipal funds;

- relations concerning creation of optimal conditions for formation, allocation and use of private funds;

- relations facilitating to the abomentioned relations in currency circulation, currency regulation, control, accounting and etc.

She notices of the absence of unified scientist conception in relation to the structure of general and special parts of financial law system as a branch of law, and allocation financial legal rules into institutions, sub-branches and sections (complex sub-branches). In fact the structure of financial law is represented by the author in the following way: general and special parts in which financial legal rules are united into institutions, sub-branches and sections (complex subbranches).

She considers that the subject of financial law is shown as two groups of social relations which realization is directly linked with forming, allocation and use of certain funds and relations mediated these processes.

Hence the author outputs branch units relating to general and special parts of financial law.

Such institutions as currency circulation, currency regulation, financial accounting, general principles, legal forms and methods of financial state activity, system of state bodies in finance area, its legal status, and legal status of party to financial relations are considered the general part of financial law by the author.

The special part is represented by the following branch units:

- budgetary law (sub-branch);

- goal centralized and extrabudgetary funds (institution);

- $\quad$ public and municipal credit (institution);

- banking activities (institution);

- insurance (institution);

- finance of public and municipal factories and profit-making organizations (institution). 
E. M. Ashmarina suggests another scheme of restructuring of financial law institutions into complex sections or complex of sub-branches. She interprets tax law, compulsory insurance, accounting law, financial control and financial responsibility as a complex of sub-branches (Ashmarina, 2009: 4-12; Ashmarina, 2004).

Professor D. V. Vinnickij examines a modern condition of development of theory of financial law rather critically. He doesn't recognize financial law not only as a branch of law effectively functioning system but theory or academic science (Vinnickij, 2009: 34-36). First of all he considered that a systemacy should be in the very law (in principles, terms, legal constructions and not in out it - in economic relations, scientists doctrines and etc). His statement about the legal practice of financial law and financial law theory begins develop as two absolutely independent realities are considered reasonable (Vinnickij, 2009: 35).

Examine the meaning and a role of systematization of law rules E. Ju. Gracheva emphasizes that the main of systematization of financial law rules is the reflection of economic content of financial relations and the legal form. And it should be directed to effective influence on the social processes in financial sphere (Gracheva, 2009: 39-43). E. Ju. Gracheva shows the special feature of following branch unit: the existence of complicated structure as it consists of financial law included both a general and special parts of financial law.

Examine of the content of modern financial law, S. V. Zapol'skij considers the priority of public tasks and interests before private property interest and subjective personal rights as the main defect of the previous financial law. Noticing a long discussion around the system of financial law, he emphasizes the following feature - "announcing finance sphere of property-power relations, we should exclude from finance law subject (i.e. its institutions from the system on facultative basis as insurance, savings business, banking credit, legal regime of investment from the subject of financial law and its system) (Zapol'skij, 2009: 59). He states that the "the practice leads as to the necessity of the creation of the universal concept of financial law regulation by the way of refusal of domination of the imperative means over dispositive ones" (Zapol'skij, 2009: 59). A. I. Hudjakov is a successive follower of public finance prevailing in financial law regulation (Hudjakov, 2009: 113-139: Hudjakov, 2010: 10-13; Hudjakov, 2009). He reasonably states that single backbone criterion should be based on the construction of any classification row. Accordingly, this author denies the possibility of inclusion in the system of financial law of such institutions: insurance, banking activity, activities at securities markets. He also denies a separation of certain branch units in sub-branches of financial law, for example tax law. He defined the subject of financial law solely in the scope of relations arising in the process of forming and distribution of public money funds which refers to financial relations by its economic nature (Hudjakov, 2009: 139).

The problem of expansion or reduction of the subject of finance law regulation and secondary branch structurization of its has undoubtedly radical vision.

According to his point of view S. V. Zapol'skij considers that internal structure of the general part of financial law has some clearness for a first approximation, the formation of the special part even has not been begun yet(Zapol'skij, 2008: 96). The considers the work of formation of modern financial law system should include a creation of the general part:

- unified principles of branch;

- subjects of financial law;

- general basics of finance and law responsibility;

- a legal regime of financial fund establishment, money assets accumulation in it and financial expenses;

- general basics of financial procedures regulation;

- legal basics of accounting and control in finance area.

The special part is suggested of the following:

- emission law;

- budgetary law;

- tax law;

- insurance law;

- public debt and public credit;

- $\quad$ savings law (Zapol'skij, 2008: 95).

D. V. Vinnickij, examine financial law as a complex law unit uniting independent law units, points out the active formation of two autonomous legal branches, tax and budgetary law, in scopes of financial law system regulation and the outcome of banking law, insurance law, currency law, amounts law regulation, securities market, finance of public and municipal factories from finance and law regulation lead to the revision of traditional approaches to financial law. According to his point of view, financial law has transformed into the complex branch including constitutional and legal institute - legal basics of monetary circulation and autonomous branches like budgetary and tax law (Vinnickij, 2002: 3042: Vinnickij, 2003: 50-51). 
Examine the problem of financial law system as a branch of law, system of science and system of teaching in the institutes, K. S. Bel'skij states that it is not true to mark out it that in the structure of the general and special parts. He divides a structure of financial law on sub-branches and institution and it is represented by the following way:

- sub-branches - emission law, budgetary law, tax law;

- public - banking law, finance and control law;

- institutions - public credit, lottery activity, securities market, different financial enterprises, accounting and other institutions (Bel'skij, 2009: 33-40).

We can determine the modern stage of development of financial law as the most impetuous development stage. But such categories of financial law as subject and financial law system have been staying the most discussion. The Modern Russian financial law literature suggests the following conception attractions to the subject regulation of financial law:

- a traditional conception which has come from the soviet financial law and is based on the basic categories of financial state activity in the field on formation, distribution and use of monetary funds;

- a concept of financial law transformation into a complex branch of law and as a result the transformation of big sections (sub-branches) into autonomous branches of law what leads to the explanation of the own subject, method and system by each of them;

- the concept of expansion of the subject of financial law at the expense of the inclusion of new market institutions into the sphere of regulation. They were absent in the Soviet period especially in the sphere of regulation not financial but other branches of law;

- the conception of forming of new branch of law which is a full contrast to all previous conceptions.

Nowadays the conception which is in the base of the public law subject definition with the help of financial law activity of public law units in the area of formation distribution and use of monetary funds cannot explain the whole potential of financial law. Being the heritage of the Soviet past it is does not allow to see that the financial law in the market conditions qualities and characteristics. The new characteristics of financial law are concluded in the fact that it has become the instrument of state influence on private finance. Despite of the fact that private finance function on the base of other principles instead of public finance the state has a magnificent on its functioning with the help of financial law rules.

The present condition of law theory with has rich Soviet traditions concerning branch specialization cannot overcome its deceleration. Unfortunately, traditional approaches of branch determination with the help of the subject and method of financial law regulation cannot give now explanation to many of phenomena of legal reality. The modern financial law having deep roots from the Soviet period of law development doesn`t explain many existing phenomena of law.

It's important to give a point of view of the academician N. I. Himicheva who examine some institutional problems of financial law at the new period of development. She states that the content and practical activity of financial law institutions not successive and doesn't correspond to constitutional rules (Himicheva, 2006: 28).

The fear of transformation of financial law is not reasonable. In fact the place of the branch in legal system is determined by social need. There should be only priority of public units of the financial sphere. Private subjects in the financial sphere must obtain respectable tools of interaction and realization of their private interests in finance sphere too. The modern financial law is burdened by the priority of public interests over the interests of common wealth of everybody. It's very well but according to the modern realities the interests of public law units is becoming absolute. For example, the situation in budgetary and tax area.

A presence of different concepts connected with the subject of financial law concerns with the financial law system. As a rule there is traditional approach to the structural elements of financial law system as branch of law in the most of researches. The appearance of new institutions of financial law has been designated. The authors suppose that the exclusion of traditional institutions from financial law system, explain the transformation of institutions and sub-branches into new autonomous branches of law or new complex sub-branches. However nowadays there is no magnificent theoretical development of systematization criterions of financial legal rules into relevant structural elements of financial law haven. There is no serious theoretical highlighting elements composition of both general and special parts of financial law in the most books devoted to financial law. Issues about universality of institutions and sub-branches and forming of financial law system are still in question. We consider that the whole special part of financial law consists of huge number of interindustry institutions united into sub-branches. In fact it can be recognized that the social relations in sphere of public and private finance are the subject of coordination regulation by both public and civil branches of law. As a result an inevitability of complex unit formation is particular in legal finance regulation.

In the obligatory introduction, please mention the aims of the article, the hypothesis, and used science methods. 
You should mention most important books and articles published in previous time.

\section{Conclusion}

We consider that the modern system of financial law is presented by the following some sub-branches: tax law, emission law, finance and control law containing a big number of financial law institutions.

\section{References}

Ashmarina E. (2009). New view on modern financial law system as a branch of law, Economic and legal problems in modern Russia, Moscow: Finacademija

Ashmarina E. (2004). Some aspects of the expansion of the subject of financial law in the Russian Federation: problems and perspectives, Moscow

Bel'skij K. (2009). About the system of financial law teaching, State and Law no. 12

Berendts E. (1914). Russain financial law. Lectures read in the Imperial college of jurisprudence

Cypkin S. (1983). Financial and legal institutes, their role in modernization of financial activity in the Soviet state, Moscow: MSU Publishing

Ermakova T. (1975). About system of financial law, Jurisprudence no.2

Gorbunova O. (1998). About subject and financial law system , Juridical world no. 5

Gracheva E. (2009). Financial control as sub-branch of financial law: definition and types, The system of financial law. The scientist and practice conference, Odessa

Gurvich M. et al (1940). Financial law. Textbook Moscow

Halfina R. (1952). About the issue of subject and system of the Soviet financial law, Issues of the Soviet administrative and financial law, Moscow

Himicheva N. (2006). Problems of financial law on modern stage of development in the Russian state, Financial law no. 4

Hudjakov A. (1988). About the issue of the system of the Soviet financial law, Izvestija AN Kaz SSR no.4

Hudjakov A. (2009). Criterions of the formation of financial law system, The system of financial law. The scientist and practice conference, Odessa

Hudjakov A. (2009). The debatable issues of financial law subject, Financial law no.3

Hudjakov A. (2010). The issue about of content of some finance and law categories, Financial law no.2

llovajskij S. (1904). (4th ed): Textbook of financial law, Odessa

Ivanov B. (1967). About system of the Soviet financial law, Issues of the Soviet financial law. Vol IX, Moscow

Janzhul I. (2002). The basics of financial theory: Theory about the state expenses, Moscow: Statut

Jarockij V. (1898). Financial law. Lectures read in the Military-juridical academy, St. Petersburg

Kazancev M. et al (2009). The institutions of financial law, Moscow

Kazancev N. (2009). The law and financial control, Moscow: Eksmo

Karaseva M. (2006). The modern problems of the formation of the financial law system, Jurisprudence no. 3

Kostjukov A. (2002). The debatable issues of subject and system of the Russian financial law. Tutorial, Omsk

Lebedev V. (2000). Financial law, Moscow: Statut

Lvov D. (1887). The course of Financial law, Kazan

Nikitinskij A. (1910). The basics of financial theory and politics, Moscow, Knigoizdatel'stvo «Polza» V. Antik i Ko

Ozerov I. (1911) (4th eds.): The basics of financial theory. Issue 1st. The teaching about general income, Moscow

Patlaevskij I. (1885). The course of financial law, Odessa

Pavljuchenko M. (2008). The development of the subject of financial law (1917-1991), Synopsis of the candidate dissertation, Moscow

Rovinskij, E. et al (1946). Financial law. Textbook Moscow

Rovinskij E. (1957). The Soviet financial law, Moscow

Rovinskij E. (1960). The general issues of theory of the Soviet financial law, Moscow

Tarasov I., Isaev A. (2004). Finance and taxes: essays of theory and politics, Moscow: Statut

Tosunjan G., Vikulin A. (2003). Towards new financial law, Financial law no. 6

Zapol'skij S. (2008). The debatable issues of the financial law theory, Moscow

Zapol'skij S. (2009). About the essence of financial law, The system of financial law. The scientist and practice conference, Odessa

Vinnickij D. (2002). The subject and system of financial law on the modern stage, Jurisprudence no.5

Vinnickij D. (2003). The basics of problem of theory of the Russian tax law, Synopsis of the candidate dissertation, Ekaterinburg

Vinnickij, D. (2009). Financial law: a chaos or a system? The financial law system. The scientist and practice conference, Odessa 
